\title{
8. Media convergence in Bhutan: Case studies in 2008 link local voices to central infrastructure
}

\section{ABSTRACII}

Evidence is produced that Bhutanese citizens are adopting many of the media and communication technologies and practices common in more developed countries, and that the government has the political will to encourage this with infrastructure spending. This article links the two and reports that infrastructure spending and legislative encouragement, especially through unique social and cultural structures, appears to enhance the growth and emergence of media enterprises, a key driver of diversity and democracy. Key limitations on further expansion are identified as the remote location of the country and the low teledensity evident in this village-based society.

Keywords: diversity, democracy, development communication, development journalism, digital divide, globalisation, media convergence

\section{KINLEY WANGMO and JOHN COKLEY \\ University of Queensland}

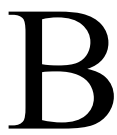

HUTAN is a small landlocked country north of India with a small population: about 635,000 people (National Statistical Bureau, 2005 ) inhabit an area of 47,000 square kilometres. Superficially, the physical communications task appears less daunting than in larger more populatedcountries, butatadeeper,morerealisticlevel,Bhutan'ssocio-political fabric, its tradition of oral communication through cultural groups, and physical barriers such as mountains, along with the 'developing' nature of the country, make the communications task more complex and at times, problematic. This research looks at the development of media convergence in Bhutan by assessing current user trends, development of media products 
as a result of modernisation and globalisation, the digital gap and literacy rate evident in communities and the infrastructure framework of Bhutanese society made evident by government structures. The discussion includes the government policy which has made Bhutan famous-possibly uniqueamong all national governments: the development policy Gross National Happiness, announced and promulgated by the Fourth King at his coronation in 1972 as an antidote to the consumerist and materialistic western concept of Gross Domestic Product (Dorji, 2005, p. 5).

\section{Literature review}

\section{Media convergence in the Bhutanese context}

Before convergence became evident in 1983 (Dupagne \& Garrison, 2006), radio, television and print media functioned as separate and independent identities. Television was largely unknown before the advent of the World Wide Web in Bhutan (1999) brought on convergence so that internet and mobile telephony, radio, television and print co-exist in an interdependent state (see Thomas, 2008; Quinn, 2006, p. xiii).

The reality or even feasibility of media convergence in developing countries depends on wide-ranging issues such as digital divide, illiteracy, cost of set-up and access to technology (James, 2003, p. 83). Diversity of ownership is also necessary (Baker, 2007) for media structures to prosper.

For instance, the project in India called $n$-Logue established a network of cheap kiosks costing about Rs.40,000 (US\$830) each to extend telecom and internet service to small towns and rural areas, including wireless equipment with antenna, cables and mast, handset and an STD-PCO meter, a Pentium $700 \mathrm{MHz}$ computer with multimedia and a colour monitor, battery backup and Indian language software to make computing relevant to non-English literate masses (James, 2003, p. 95). But while such initiatives are important for equal distribution of information through ICTs such initiatives can also bring about social change (Thomas, 2007, p. 1). Consider, for example, the case of terminology in computer software: as Kinley Dorji, editor-in-chief of the national newspaper Kuensel explains (2007): 'The software giant, Microsoft, decided to change the term "Dzongkha [the Bhutanese national language]" to "Tibetan-Bhutan" in its software not knowing, or caring, about the consequences or reactions'. That software uptake failed (Dorji, 2007). Elsewhere, the initial Dzongkha Linux roll-out failed to function fully and did 
not support PowerPoint and Word Excel (Wangchuk, 2007). These, alongside the historical dependency on English among Bhutan's residents and media, are relevant points for discussion of Massey and Levy's dependency theory of development (1999, p. 527).

Based on a study of convergence in Pacific countries, Duffield, Watson and Hayes (2008) argue that it is not feasible for poorer countries to gain access to what they term the 'cyber bandwagon' while it is traveling at speed. They argue that while new media is a growth area known to deliver high productivity, it requires investment and infrastructure and assumes preparedness on the part of users regarding their wealth, education, language capacities and cultural adaptability. This is supported by Roy's description of convergence in India (2005, p. 132) which suggests that ICT is a major motivating force for greater efficiency, reducing costs by savings in labour, materials, energy and other factors of production, as well as developing new products and boosting new demands. The growing population of so-called 'netizens', bloggers, and citizen journalists there provides alternative media to citizens but also industrial capacity in hardware and software production.

Nevertheless, Martin (in Massey \& Levy 1999, p. 524) notes that news organisations require sizeable staff cohorts to enact any discernibly high degree of interactivity into web news products, suggesting that (again focusing on journalism as one aspect of convergence) interactive online journalism is labour and capital-intensive. But even this can be the foundation for a viable business model (Thelin, 2006, p. 17) when enterprises amortize the cost of production against the cost of customer acquisition and gaining market share.

Massey and Levy (1999, p. 524) argue that interactivity is among the most distinctive contributions of online journalism to news consumers and the business of disseminating daily news, in contrast with the older notion of passive media spectators (Jenkins, 2006).

\section{Experiences of developing countries: Asia-Pacific and Bhutan}

In the Asia-Pacific region, there were 27 million people using the internet at the end of last century (NUA internet survey, 1999, in Massey, 1999), a growth of 58 percent over NUA's estimate from May 1998 and accounting for 17 percent of the world's estimated 158.5 million internet users. But by this time (1999) Bhutan had just opened up only to television and the World Wide Web. By the end of 2005, media companies in Southeast Asia embraced convergence more widely (Quinn, 2006, p. xv). 
The uneven dissemination and appropriation of mobile media is nowhere more apparent than in the Asia-Pacific. There are uneven penetration rates and usages of mobile technologies - from ' $3 \mathrm{G}$ centres' ( $3^{\text {rd }}$ generation, i.e. mobile with broadband) ranging from Tokyo and Seoul to the Philippines, which is known as the text capital of the world with over 300 million messages sent daily and with many Filipinos participating in the 'texting god' phenomenon (Ellwood-Clayton, 2003, in Hjorth 2007 p. 371). Correspondingly in Bhutan on 7 April 2008, Bhutan Telecom Limited launched its own third generation mobile phone standard and technology (3G) (Kuensel) in the capital, Thimphu, which allows internet browsing, email and video telephony.

Ehrenberg (1998 as seen in James 2003 p. 87) notes that most of the population of developing countries lives in rural and often isolated areas and access to information and telecommunication is essential for development of these areas. There is inadequate or no development tools in these areas and the people are caught in vicious circles. However, Ehrenberg also notes that it is neither impossible to supply internet to rural areas if they are supported by subsidies, nor difficult to show that the participants in such Internet projects derive substantial benefits. The USAID agreed to assist in developing internet connectivity in 20 African countries (Roy, 2005, p. 130), but in return the African countries had to liberalise their markets to include third-party internet service providers and to adopt policies which allowed for unrestricted flow of information.

In Bhutan, the report, Information and Communications Technology (ICT) for Bhutan (Ministry of Information and Communication 2003, p. 1) mandates that ICTs may not replace safe drinking water, shelter or food, but are indispensable as an instrument of sustainable socio-economic development. The report notes that affordable and usable ICTs can transform the way societies work, entertain, study, govern and live, at individual, organisational, sector, vocational and national levels. It also notes that ICTs offer the opportunity to leapfrog the key stages of industrialisation and to transform the agrarian Bhutanese society into an information society.

Bhutan Telecom is the sole provider of all telecommunications networks in the country but not all derived services such as ISPs. The national teledensity in 2003 stood at 3.25 per 100 inhabitants overall but rural teledensity was very low (about 0.01 percent) and this is significant because about 69 percent of Bhutanese live in rural areas (National Statistic Bureau, 2005) with only 76 of the 201 Geogs (groups of villages) connected to the national network. In the 
fourth year of its establishment, one of the three ISPs, DrukNet had about 2000 customers. There were about 7000 computers nationwide. At the most 5000 people were accessing the internet, which was less than 1 per 100 inhabitants. Computer and ICT literacy is very low. Literacy rate is 59.5 percent, (census report, 2005). Currently, all newspapers, radio stations, and television operated converged outlets in their own small ways by publishing online.

\section{Bhutanese society}

To the outside world Bhutan is known as a poor developing country dependant on foreign aid. It is also known for remaining closed to the outside world until recently. The process of modernisation began in the 1950s during the reign of Third King Jigme Dorji Wangchuck and was further carried out by his son, Fourth King Jigme Singye Wangchuck. In half a century of the modernising process, infrastructures such as roads, schools and hospitals and human resources were developed. It is noted that, relevant to the current study, foreign aid has also assisted the development of media enterprises: the World Association of Newspapers and the group Media Helping Media (Mishra 2007 n.p.); the Ministry of Foreign Affairs of Denmark (2009, p. 7); and the World Bank (2009).

The majority of the population are Buddhist and therefore the Bhutanese's way of life and socio-cultural development are influenced by Buddhist beliefs and teachings. The process of modernisation has brought about a desire for material wellbeing. People's aspirations, goals and the definition of a happy and content life are changing, especially in the urban areas. Rural to urban migration is on the rise and cities, especially the capital, are facing the effect of migration such as urban housing shortage, unemployment and increase in crime rates. Dzongkha is the national language, mainly endemic. It has been suggested (Avieson 2009) that the combination of this regional endemicity, the fact that Dzongkha carries a mostly oral rather than written tradition, and the lack of a diffused 'newspaper reading habit' works against the viability of newspapers in the Bhutanese market.

The first telecommunications network began in 1963 as part of the First Five Year Plan (1961-1966) to support road construction services. Modern telecommunications network development process began only in the early 1990s and a fully digital national network, connecting all the 20 district headquarters and major towns, was established by 1998. Internet services were introduced in June 1999 with the establishment of DrukNet, the first and, at 
the time of writing, one of three internet service providers (ISP) (see Ministry of Information and Communication 2003).

In the process of modernising, Bhutan has been exposed to even newer technologies and the effects have been noticeable (Dorji, n.d.).

\section{Types of media}

Oral tradition has been the dominant communication form in Bhutan for ages, and when the first newspaper was introduced in the 1980s, it captured only a small segment of the society. The reach was limited, as already pointed out, by the physical barriers as well as the low literacy rate in the country. Radio- the oldest form of established media among the Bhutanese, introduced early in the 1970s - has a better outreach compared with print. Pek and Dorji (2005, p.3) suggest about 77 percent of the population listen to Bhutan Broadcasting Service Corporation's radio station. Furthermore, it was also indicated that with the introduction of television there was a concern that the society might jump from an oral to a visual media without developing a literary tradition. In the middle of this, radio has been the main information medium for rural citizens, reaching all the country's 20 districts, while print media reached the literate and policy makers (Pek \& Dorji 2005, p. 3). Television, specifically international news, has made its strongest impact on the urban population, especially youth.

\section{Benchmarking}

Phuntsho Rapten (2001, p. 172) notes that mass media in Bhutan primarily refers to radio, newspaper, cinema, television and internet. In 1998 a benchmarking survey was conducted in five districts of Thimphu, Paro, Chukkha, Punakha and Wangduephodrang and the findings offer an insight into media penetration in Bhutan.

Among all households in five districts, 63.1 percent owned at least one radio receiver, 22.6 percent own a tape recorder, 6.9 percent own a TV screen, 8.4 percent own a video player or recorder, and 6.5 percent own a telephone. Although Kuensel was also widely circulated in the country, its readership in the villages was very limited due to a low literacy level (Phuntsho Rapten, 2001, p. 172).

This article documents a participative-observation study by one of the authors conducted in 2008. Co-author Wangmo is a journalist who lives 
and works in the Bhutanese media environment and researches new media opportunities.

\section{Findings}

Before 2006 there was no provision for private media enterprises to operate in Bhutan. The first private newspaper opened in 2006, after which a series of other private media businesses emerged. The privatisation of the media was initiated by the fourth King as part of the democratisation process. This section deals with the emergence, role and impact of different media organisations and companies.

\section{Table 1: Radio enterprises in Bhutan, 2009}

\begin{tabular}{|c|c|c|c|c|}
\hline Name & $\begin{array}{c}\text { Year } \\
\text { established }\end{array}$ & Type & Editions & Ownership \\
\hline BBS & 1973 & $\begin{array}{l}\text { News \& rural } \\
\text { focus }\end{array}$ & $\begin{array}{l}\text { English } \\
\text { Sherpenn Sherpa } \\
\text { Nepali } \\
\text { Jaga Nath Sharma \& Anima } \\
\text { Chhertri } \\
\text { Sharchop } \\
\text { Lhanga Tshering \& Sonam Zam } \\
\text { Dzongkha } \\
\text { Phub Gyeltshen \& Yeshey Dorji }\end{array}$ & $\begin{array}{l}\text { Government- } \\
\text { owned corp }\end{array}$ \\
\hline Radio Valley & 2005 & Entertainment & Lhendup Dechen Dorji & Private \\
\hline Kuzoo FM & 2006 & $\begin{array}{c}\text { Youth \& } \\
\text { Entertainment }\end{array}$ & Chuki Tshomo & NGO \\
\hline Centennial & 2008 & $\begin{array}{c}\text { News \& } \\
\text { Entertainment }\end{array}$ & Dorji Wangechuk & Private \\
\hline
\end{tabular}

\section{Radio}

\section{BBS Radio}

Like the other media and telecommunication services, radio was introduced first in the capital. It was started by the National Youth Association of Bhu$\tan$ (NYAB) in November 1973 with a 400-watt transmitter rented from the telegraph office (Bhutan Broadcasting Service Corporation). The radio aired a 30-minute news and music programme on Sundays. The government later nationalised the station, saying it needed a more professional approach and in 1986 it was re-named as the Bhutan Broadcasting Service (BBS). The 
new government-owned radio station had a small studio with a $10 \mathrm{KW}$ shortwave transmitter and broadcasting increased to three hours every day. Some said (Acharya, 2005) the government took over the radio station because it recognised its potential as a development communication tool. In 1992, $B B S$ was given autonomy by Royal Edict but remains a highly subsidised government-owned corporation. The station eventually introduced an FM service to the western part of the country (around the capital) and slowly extended the service to central parts, extending country-wide in 2005: since then rural Bhutanese have been able to tune into programmes with great clarity (Dendup, 2008). The station broadcasts 15 hours daily in four different languages: Dzongkha, Sharchop, Lhotsamkha and English, including news bulletins, public announcements, prayer and recitations and education programmes on health and sanitation, agriculture, youth and sports, social issues, and zakar (astrology).

\section{Kuzoo FM}

The first private radio station in the capital was Kuzoo FM, going on air in September 2006 with 15 permanent staff. Kuzoo FM is part of a bigger nongovernmental organisation called Kuzoo Society, which also has an interactive weblog called Kuzoo.net and a newsletter. The FM radio caters for youth and concentrates on educative programs about current affairs and social issues and plays contemporary international music (such as rock and pop) and modern Bhutanese music. Youth volunteers work as presenters. Kuzoo Fm has two stations: one each for English and Dzongkha programmes and are available in 14 of the 20 districts. Currently, Kuzoo FM has seven English and 12 Dzongkha presenters.

\section{Radio Valley}

Another private FM station, Radio Valley, was launched in April 2007, owned by entrepreneur Kinley Wangchuk, and employing nine presenters. Management aims to provide music and entertainment and promotes and helps aspiring Bhutanese musicians and singers with music and recording. This station reaches only residents of Thimphu and Paro and carries programs in Dzongkha.

\section{Centennial Radio}

The fourth FM radio station, Centennial Radio, targets an urban audience over 25 years old. It was launched in March 2008 and its programming 


\section{PUBLIC RIGHT TO KNOW}

focuses on news, current affairs, music and entertainment (Pelden, 2008).

It has been planning a second channel, Rigsar FM, which at time of writing was expected to be launched in 2009. The station employs 13 full-time and 15 part-time staff.

\section{Table 2: Newspaper enterprises in Bhutan, 2009}

\begin{tabular}{|l|l|l|l|l|}
\hline \multicolumn{1}{|c|}{ Name } & \multicolumn{1}{|c|}{$\begin{array}{c}\text { Year } \\
\text { established }\end{array}$} & \multicolumn{1}{|c|}{ Type } & \multicolumn{1}{c|}{$\begin{array}{c}\text { Chief editors/ } \\
\text { editors }\end{array}$} & \multicolumn{1}{|c|}{ Ownership } \\
\hline Kuensel & August 1986 & Newspaper & $\begin{array}{l}\text { English } \\
\text { Dasho Kinley Dorji } \\
\text { Dzongkha } \\
\text { Rinzin Wangchuk }\end{array}$ & $\begin{array}{l}\text { Public Limited } \\
\text { Company (Govern- } \\
\text { ment and private) }\end{array}$ \\
\hline Bhutan Times & $\begin{array}{c}\text { February } \\
2006\end{array}$ & Newspaper & Gopilal Acharya & $\begin{array}{l}\text { Private Limited } \\
\text { Company }\end{array}$ \\
\hline Bhutan Observer & $\begin{array}{c}\text { June 2006 } \\
\text { Bhutan Today }\end{array}$ & Newspaper & Tashi P Wangdi & $\begin{array}{l}\text { Private } \\
\text { ownership }\end{array}$ \\
\hline 2008 & Newspaper & Tenzin Dorji & $\begin{array}{l}\text { Private } \\
\text { ownership }\end{array}$ \\
\hline
\end{tabular}

\section{Newspapers}

\section{Kuensel}

In the mid-1960s, Kuensel was introduced as a fortnightly news bulletin by the government and later in 1986 published as a government newspaper in English, Dzongkha and Lhotshamkha. In 1992 it was granted autonomy by the fourth King and in 2005 shares (up to 49 percent) were offered for private sale. It grew from a news-bulletin to a 20-page weekly paper in 1986 to a 14 page bi-weekly paper. At time of writing the paper plans to go daily in 2009.

In 2001, after internet was introduced, Kuensel started a daily online news service and in 2005, set up a regional printing press outside the capital, in Kanglung, Trashigang, cutting the previous delivery time of papers from three days. Public buses are used to ship Kuensel to other districts (Pek 2003, p. 17) where private agents collect papers for distribution. In remote places, papers are carried by messengers and travelers.

The deputy editor of Kuensel, Ugyen Penjore (personal communication 2008) said the paper had a readership of about 13,000 for its Wednesday edition and 15,000 for its Saturday edition. Website traffic had reached 3000 
visitors per day. The newspaper employs 14 reporters, including the editors in the English editorial team and seven in the Dzongkha editorial team.

Just as FM radio stations sprouted with privatisation, two newspapers were immediately launched in 2006. Bhutan Media Services, a private media service firm launched its weekly newspaper Bhutan Times (BT) in April that year and the Bhutan Observer in June 2006.

\section{Bhutan Times}

$B T$ started with English publications after the government approved its request to publish only in English for one year according to managing editor of Bhutan Times, Tashi Dorji (personal communication 2008). The Media Act mandates that a newspaper must have a Dzongkha version and has to have a nationwide circulation. $B T$ is a private limited company, headed by a board of directors, who are major shareholders in the company. The company is headed by a managing director, Tenzin Rigden, who is a former Kuensel editor. Initially, it employed about 40 people and at time of writing it employed about 90 . The paper was printed by a private firm when it first started but now $B T$ has its own printing house. It claims to have a circulation of about 15,000 and the paper now publishes twice a week.

\section{Bhutan Observer}

The Bhutan Observer launched as a weekly paper in June 2006 in both English and Dzongkha. It was started by a businessman, Mani Dorji, who owned the KMT printing and publishing house. The paper's ownership has since changed from Mani Dorji to his brother Tenzin Wangdi and his wife, Phuntsho Wangmo. They act as the managing director and head of operations. The editorial is headed by editor-in-chief, Tashi P Wangdi, who was the former editor-in-chief for BT and editor for Kuensel. The Bhutan Observer also claims a circulation of 15,000 .

\section{Bhutan Today}

The third private newspaper, Bhutan Today, was launched in October 2008 and became the country's first daily newspaper (BBS.com.bt 2008). The managing editor was Tenzin Dorji, who announced at the time that the paper would 'strive to provide a new perspective' and that 'accuracy, balanced reporting and credibility coupled with simplicity in writing and presentation will be the paper's guiding principle' (BBS.com.bt 2008).

The paper costs Nu.5, roughly half the price of the other papers (@ Nu. 8-10 daily). It employs four editors and 16 reporters and four of those work 
outside the capital in Tashigang, Gelephu, Phuentsholing and Bumthang. Tenzin Dorji said he hoped to have reporters in all 20 Dzongkhags by the middle of the year (BBS.com.bt 2008).

Table 3: Free-to-air television enterprises in Bhutan, 2009
\begin{tabular}{|c|c|c|l|l|}
\hline Name & $\begin{array}{c}\text { Year } \\
\text { established }\end{array}$ & Type & \multicolumn{1}{|c|}{$\begin{array}{c}\text { Chief editors/ } \\
\text { editors }\end{array}$} & Ownership \\
\hline BBSC TV & June 2,1999 & News & $\begin{array}{l}\text { English } \\
\text { Kaka Tshering \& } \\
\text { Tshewang Dendup } \\
\text { Dzongkha } \\
\text { Sonam Zam \& } \\
\text { Sonam Tobgay }\end{array}$ & Government \\
\hline
\end{tabular}

\section{Television}

Before 1999, Bhutanese law prohibited ownership and watching of television. But that year, during the Fourth King's silver jubilee of coronation, some satellite reception and cable services were introduced in the capital for hotels and residences. International news and entertainment channels such as the BBC, CNN, NDTV and Star TV began to have an impact on those city viewers.

\section{Cable Television}

Cable television was introduced in the country along with the internet in 1999. When television was introduced the Bhutanese population was suddenly overrun by about 45 international channels. Pek (2003, p. 20) states that in just about two years an estimated 33 licensed cable operators and subscribers increased to 12,000 (142 percent) in 18 districts. The impact of the introduction of cable television was felt on the culture. Dorji and Pek (2005) argue that there is a growing concern over the perceived dilution of culture by the international television channels. Some of the channels on music and sports were removed. However, the decision to take 15 channels out of the cable system has drawn strong response from television viewers, some believing that they have been seriously deprived and other cable operators expressing relief at some form of review and censorship (Dorji, 2005). The editor however argues that viewers who expressed passionate views on the cuts should spare a moment to reflect on these important issues. At present, 
there are 52 cable TV operators operating in all 20 Dzongkhag headquarters and other populated areas, (Information, Communication and Transport Sectors in Bhutan, 2007). These operators provide up to 31 foreign channels including the mandatory BBS channel.

$B B S T V$

$B B S T V$ was launched in the capital in 1999 with a daily one-hour broadcast in Dzongkha and English. But $B B S$ was limited in professional capability and quality of content (BBS.com website, 2008). It was also limited to audiences in the capital and nearby areas. In February 2006 BBS launched its nationwide service on satellite and its broadcast timing increased to five hours daily. $B B S$ has bureau offices set up in all districts.

\section{Alternative media}

Bhutan has a strong oral tradition and has taken advantage of this to communicate and disseminate information in the country through women's groups, local leaders, and health groups. Apart from established media there are also pamphlets, magazines and journals which provide information to the public, especially those who are literate. Foreign books, magazines and comic books are also available through bookshops and the Internet.

\section{The oral tradition}

Some of the Bhutanese oral literary genres (Penjore, 2005, p. 53) are srung (folktales), glu gzhas (folk songs), dpe gtam (proverb) gtam rgyud (legend) and blo ze (ballad), tsang mo (western equivalent of quatrain), gab tshig (riddle), dgod bra (joke); folktale is the most popular and widely available literary genre. Some of the prominent oral forms of communication in the pre-dominantly oral Bhutanese society have been the works carried out by the Amtsu Tshogpa (National Women's Association of Bhutan), and those of the chimis (elected representatives to the National Assembly) and the gups (village headmen).

\section{The Amtsu Tshogpa}

The National Women's Association of Bhutan (NWAB) was instituted by the 53rd session of the National Assembly in 1981 with the primary role of advancing women. While the association has a limited number of employees, almost all districts have volunteer groups which carry out the bulk of the activities of the association. The volunteers include villagers, civil 
servants, businessmen and women, including the clergy. The heads of the volunteer groups in the districts are the wives of the dzongdas (district administrators), responsible for planning and implementing the association's activities at the grassroots levels. These women carry out their activities by setting up meetings and before staged shows and theatrical performances with deep social messages. Some of the activities carried out by the association are creating awareness on sexually transmitted diseases, creating employment opportunities among teenage mothers, supporting handicapped and helpless women and families in the rural areas, and sponsoring education of under-privileged children.

\section{The gups and chimis}

The gups (block administrator) play a major role in disseminating information from the district or the centre to the communities and vice-versa. Chimis on the other hand are elected representatives to the National Assembly and they act as a bridge between the government and the communities in educating people about the national matters and at the same time informing the government about priorities of the communities. The National Assembly was established in 1953. Both the gups (201 in total) and the chimis (103) are elected by adult franchise and usually are people without any or little formal education background, but who are well known, respected or from a prominent family in their communities.

\section{International newspapers and magazines, books}

The first bookshop opened in 1978 but today in Bhutan, a wide variety of international books, newspapers and magazines are available, most of which come from India. As of December 2002, there were 162 bookshops catering for the international information needs of the Bhutanese (Pek, 2003, p. 17). However, 91 percent of the existing 162 shops were located in the capital (Ibid). While book sections offer world bestsellers and popular contemporary and classical writers, the newspaper and magazine sections are dominated by products from India. Pek (op. cit.) suggests this is because the Indian products are cheaper. Otherwise, comics like Archie and Tin Tin are popular among the youth. The few publishing houses such as KMT Press and Pe-Khang Enterprises publish in both Dzongkha and English but print runs and products are very small, albeit expanding (Pek, 2003). 


\section{Journals, newsletters and magazines}

The Center for Bhutan Studies (CBS) archives (both in print and online available to the public and scholars) biannual journals which cover a wide range of subject matter: from socio-cultural to political aspects of Bhutan, the newsletters of government departments, a journal from Sherubtse College and publications by schools and educational institutes make up the print media (outside mainstream media). There are also a few Bhutanese magazines such as Bhutan and Bhutan Now published by Mediacom Consultancy and Bhutan Media Services. The national airline also publishes an in-flight magazine including standard features of the genre such as an introduction to Bhutan society and destination travel articles.

\section{Film}

The Indian cinema institution, Bollywood, has had a major impact on Bhutanese society, and the very recent Bhutanese film industry produces copies of many Indian movies. Present in almost all Bhutanese movies are the usual themes of 'boy meets girl' and the 'songs and dance sequence'. They have become a pertinent element in Bhutanese movies, and were basically picked up from the Indian movie. The film production industry began in the 1990s, spurred by the change from celluloid to the more portable video technology and 'boomed' after 2000 because of digital technology (Pek, 2003, p. 24). An average of 12 films are released in Bhutan each year and screened mostly in the larger towns with bigger audiences. Audience reception of these mostly Hindi-language films is unimpeded by language, since audience members (whose native language might be either Dzongkha or Nepali) have been hearing and understanding Hindi on screen since they were young. At time of writing there were eight cinemas in the country: two in the capital, two in Phuentsholing (a Bhutanese town near the Indian border) and one each in Gelephu, Samtse and Gomtu and Samdrup Jongkhar. The first theatre was built in 1970s in Phuentsholing. Video rentals also cropped up during the late 1970 s and by 2002 there were nearly 200 licensed rental shops, mostly in the capital. But even this number has reduced to 136 under the impact of television flooding houses with a variety of channels and programmes (Pek, 2003, p. 24).

\section{Music}

The Bhutanese music industry also takes its lead from Bollywood, 
becoming more homegenised with the use of non-traditional instruments such as electric drum, guitar, and piano. This has given rise to the new genre of Bhutanese music called rigsar ('new music'). There are more than 40 licensed audio-visual production companies, and music production has been the fastest growing media in the past decade (Dorji, 2005). The recent emergence of private FM radio stations in the capital means Bhutanese youth have found an outlet to showcase their western-inspired music talents. Rigsar music neither integrates nor promotes traditional values and does not attain the artistic refinement/standards of traditional songs (Pek, 2003, p. 26).

\section{Internet-linked telephony}

Private blogs are largely related to individual interests like personal journals, sports, music, film and politics. Weblogs and sites like Kuzuzanpo.net and Kuzoo.com also provide fledgling writers and poets with an audience. On an average three in 100 people have telephones (E-readiness, 2003) and by March 2008 b-mobile subscribers in Thimphu and Paro could access the internet. There are 26 leased line subscribers with an estimated 1050 to 2000 computers connected to these lines. There are also about a dozen internet cafes, seven of them in Thimphu. The government's official web portalwww.bhutan.gov.bt - attempts to provide information on all government agencies, especially their activities and services (Pek, 2003, p. 22). One of the busiest Bhutanese websites is the Kuenselonline.com the online version of the Kuensel newspaper. Discussion forums on online newspapers, the Druknet chat rooms, group or private blogs and social interaction spaces like YouTube, Facebook and hi5 are increasingly making people more interactive. Discussion forums like the one on kuenselonline sees discussion of topical issues on politics, media and social issues. Since internet users are largely civil servants, or corporate and private employees who have access to Internet, sometimes the discussions in the forum are restricted.

\section{Summary of findings}

\section{Established media}

Of the four radio stations evident in Bhutan at time of writing, the oldest is also the only government-owned and operation enterprise. Three privatecommercial or non-for-profit-stations have commenced broadcasting after legislation in 2005 allowed private news media companies to emerge. 
There remains just one free-to-air television broadcaster in Bhutan, the government-owned BBSC. However, data reveals that since 1999, at least 52 licensed private cable television operators had set up by 2007, disseminating at least 31 international channels. This is augmented by an unknown but quantifiable number of satellite television receivers in private as well as institutional hands, also giving access to those international channels and some others.

Until 2008 there were three newspapers circulating in Bhutan; now there are four. One of these was owned by the public-private partnership Kuensel enterprise, launched in 1986, while the other three included one publicly listed and owned company and two private firms, two of them launched in 2006.

Use of established external news websites: No evidence of institutional blocking of news websites has been found among clients of Bhutan's main ISP, Druknet (the 1600 customers and 5000 casual dial-up users). However, some blocking does occur of selected sites under cultural censorship rules, such as sites carrying explicit sexual images.

\section{Alternative media}

Data reveals a large network of institutional and culturally sponsored sites of news and media production and distribution. These are especially the Amtsu Tshogpa (Women's Association) and the chimis (elected representatives to the National Assembly) and the gups (village headmen). Without institutional and community support, these networks and their media products and effects, would not exist.

\section{Discussion}

Media in Bhutan were limited to government ownership and control until a royal decree in 1992 allowed some privatisation (Pek 2003, p. 14). In a sense, this was a new start for Bhutanese media, which had operated as a singularity under royal decree. After the liberalisation 1992, the single media channel was allowed to fragment in a way which reflects the centuries-old development of the multichanneled media institutions of the West. And since years of the early 21 st century, that fragmentation has also followed the principles of convergence identified by Dupagne and Garrison (2006) leading to a greater intensification of online and wireless telephony production and distribution of news and media products.

Essentially, though, data support the hypothesis that media expansion in Bhutan, leading to diffusion of technologies and enterprises and a greater 
uptake of media channels by citizens, has been enabled principally by government decree, legislation and investment in infrastructure. Without the decree of 1992, the enterprises recorded in our findings might not have come about. And we suggest it is clear that without the initial and continued investment by the government in newspaper, radio, television and internet facilities, neither would have this uptake and expansion continued to its present state.

With a literacy rate of about 54 percent, Pek $(2003$, p. 15) states that the readership is small and with oral tradition still strong, radio continues to be the most effective media since radio players are cheaper and portable for rural Bhutanese, especially for the rural communities. But this has not reduced the later impact of newspapers and television. These have become popular among elite decision makers and print media have dominated as a source of current affairs news and issues related to government and politics.

Before the privatisation of media Kuensel and BBS, which were both started by the government and ran on government subsidies, were seen as government mouthpieces (Acharya, 2005, p. 9). Even after subsidy to Kuensel was stopped in 1998 the reputation persisted. Privatisation has not only brought about diversity but also given people alternative media.

Amid the diversity, some newspapers have tried to attract the youth, who otherwise did not see a newspaper as something they should read. But to attract the youth dumbing-down elements have started to infiltrate the newspaper business. For the same purpose, that of giving youth a voice, Kuzoo Society was started and when Kuzoo FM began broadcasting, it immediately connected with the urban youth. Similarly Radio Valley connected with the youth and young adults (20-30s).

The FM stations have also given a boost to the local music industry alongside the otherwise already popular Western music. The radios provide an outlet for budding artists and musicians for their creativity in composing songs and music. Amid all these developments in the media the internet is creating its own small revolution in Bhutan. All the media houses and organisations discussed have a website, but this caters mainly to the educated urbanites that have access to internet.

More broadly, businesses have their websites which have helped them reach a larger market. People use the cell-phones to send text messages, listen to FM radio stations, take photographs and edit them on the phone or shoot video clips. The BBSTV can be received on some Chinese made mobile phones (Wangdi, personal communication, 16 April 2008). 
The government has become more transparent and interactive with most of its ministries and departments having established websites where people can access information or send emails and get feedback. Media houses_radio, print, and broadcast - have converged in their own small ways, and almost all the media have an online presence. The websites may not incorporate high level interactive or multimedia systems or functions but the websites exist nonetheless. Some of the common features in websites are discussion forums, polls, feedback, Q\&A.

\section{Conclusion}

The Bhutanese Fourth King's coronation speech elevating Gross National Happiness to the international agenda required specific actions for its enablement. Among these actions were the political and economic steps to establish media freedoms, especially those relevant to the process of journalism. While this article does not refer specifically to media freedoms which might or might not be enjoyed by journalists and citizens of Bhutan, it clearly identifies the heightened level of media diversity now available in Bhutan, which strongly suggests the availability of media freedoms. Media freedoms in whatever form could not have commenced without the king's emphasis on infrastructure development and training of media professionals, and the recognition of the need to make media independent and sustainable. The contribution of foreign aid (cited earlier in this article) is also noted. Today, royal decrees need to be enshrined in legislation (Pek, 2003, p. 14) for them to continue in the contemporary liberalizing environment. There is evidence of political will in the government's movement to create a secure, sustainable, affordable and appropriate ICT access network connecting all districts and blocks, educational institutions and hospitals to the global infrastructure and to develop adequate human resources.

Key challenges still face Bhutan, such as the high cost of capital investment and low teledensity, high cost of hardware and software, low computer and ICT literacy, high internet access cost, limited appropriate application and lack of local content, lack of ICT skills and capacity, high telecom tariffs, and lack of awareness in general (Ministry of Information and Communication, 2003). 


\section{References}

Acharya, G. (2005). The 2002 elections and the Bhutanese media. Retrieved on 30 March 2009, from Orebro University: www.magj.se/pdf/Gopilal\%20Acharya. pdf

Avieson, Bunty (2009) consultant to Bhutan Observer, Thimphu, comments made at UN conference July 7, 2009, and reported at the Solutions Exchange Bhutan website. Retrieved in September, from www.solutionexchange-un. net.bt/(A(8EN8NMVmygEkAAAAZDg2M2MxM2QtYmRjOS00MWYxLWIwNj MtNjg3NTBkZmFmOWQ5TNh4kr83jg48Zuh4_6P-hgqNRcY1))/media_details. aspx?NewsId $=16$

Baker, C. E. (2007). Media concentration and democracy: Why ownership matters. Cambridge: Cambridge University Press.

Bhutan Today Launched. (2008, October 31). Retrieved on 30 March 2009, from Bhutan Broadcasting Service Corporation: www.bbs.com.bt/Bhutan\%20Today\%20 launched.html

Dema, K. (2007). Radio Valley goes on air. Retrieved on 30 March 2009, from Kuenselonline: http://kuenselonline.com/modules.php?name=News\&file=articl e\&sid $=8330$

Dendup, T. (2008) FMrules air waves. Retrieved on 30 March 2009, from Kuensel online: www.kuenselonline.com/modules.php?name $=$ News\&file $=$ article\&sid $=10025$

Dorji, K. \& Pek, S. S. (2005). The Bhutanese media in the service of the public. Paper presented at the second conference on Gross National Happiness. Antigonish, Nova Scotia, June 20-24.

Dorji, K. (2005).The television debate. Retrieved on 30 March 2009, from Kuenselonline:http://kuenselonline.com/modules.php?name=News\&file=article $\&$ sid $=5208$

Dorji, K. (2007). Old story, new lessons. Retrieved 30 March 2009, from Kuenselonline:www.kuenselonline.com/modules.php?name=News\&file=article $\& \operatorname{sid}=8503$

Dorji L.Y. ( n.d). The Microsoft Unlimited Potential E-centers in Bhutan: Using ICT for development. Journal of Bhutan Studies. Retrieved on 30 March 2009, from www.bhutanstudies.org.bt/admin/pubFiles/M-10.pdf

GMCT Information and Communication Technologies. (2003). Bhutan e-readiness report. Retrieved on 30 March 2009, from Department of Information and Communication website: www.dit.gov.bt/publications/ereadiness.pdf

Duffield, L. R., Hayes, M. D., \& Watson, A. H. A. (2008). Media and communication capacities in the Pacific region. eJournalist, 8(1), 21-34.

Dupagne, M. \& Garrison, B. (2006). The meaning and influence of convergence: A case study of media convergence at Media General's Tampa News Centre. Journalism Studies, 7(2), 237-255 DOI: 10.1080/14616700500533569

James, J. (2003). Bridging the global digital divide. Corwall: MPG Books Ltd.

Jenkins, H. (2006). Convergence culture: Where old and new media collide. New York and London: NYU Press. 
Jussawala, M. (1996). South East Asia. In MacLeod, V. (Ed), Media ownership and control in the age of convergence ( $\mathrm{pp}$ 215-228). United Kingdom: International Institute of Communications. 215-228.

Gups play an important role. (1994, March, 19). Kuensel. p. 12.

Kuensel expands. (1996, August 17). Kuensel. p. 1.

Images of the decade. (1996, August 24). Kuensel. p. 1.

Gups, not Chimis, should represent people in National Assembly. (1997, November 8). Kuensel. p. 3.

Gups and Chimis have an important role.(1998, February 6). Kuensel. p. 6.

Kuensel to begin online daily papers (2001, April 14). Kuensel. p. 20.

Kuensel goes daily. (2001, June 2). Kuensel. p. 1.

The gup's new status. (2002, December 14). Kuensel. Editorial page.

Chimis ask for tax exemption on small rural businesses. (2003, August 2). Kuensel.p 5.

Kuensel printed in Kanglung. (2005, December 17). Kuensel. p. 1

No ceiling on Kuensel shares. (2006, May 13). Kuensel. p. 1, p. 12.

Statistics: a foundation for planning. (2006, April 29). Kuensel. p. 1; p. 12.

Kuzoo.net (2006). Kuzоo FM. Retrieved on 30 March 2009, from Kuzoo: www.kuzoo.net

Massey, B. L \& Levy, M.R. (1999),.Asia: A dependency theory analysis. International Communication Gazette, 61(6), 523-538. DOI: 10.1177/0016549299061006005

Merinews.com (2008). Glimpses 2007. Editorial. Merinews.com January.

Ministry of Foreign Affairs of Denmark (2009) Asiatisk Plads 2, DK-1448 København K, Denmark. Retrieved in September 2009, from www.netpublikationer.dk/ um/9281/index.htm

Ministry of Information and Communications. (2007). Information, communication and transport sectors in Bhutan: A special report. Retrieved on 30 March 2009, from Ministry of Information and Communications: www.moic.gov.bt/pdf/ moicreport.pdf

Ministry of Information and Communication. (2003). ICT for Bhutan. Retrieved on 30 March 2009, from Ministry of Information and Communication: www.apdip. net/project/2003/asian-forum/resources/bt-ict.pdf

Mishra, T.P. (2007). Aid offered to save Bhutan paper. Retrieved in September 2009, from OSDIR website http:/osdir.com/ml/culture.region.india.zestmedia/2007-05/ msg00003.html

Murelli, E. (2002). Breaking the digital divide: Implications for developing countries. n.p.: Commonwealth Secretariat and SFI Publishing.

National Statistical Bureau. (2005). PHBC factsheet. Retrieved on 30 March 2009, from National Statistical Bureau: www.nsb.gov.bt:8080/publication/pubs/PHCBfactsheet2005.pdf

National Women's Association of Bhutan. (n.d.). From the president. Retrieved on 30 March 2009, from National Women's Association of Bhutan: www.nwabbhutan. org.bt/ 
Palden, T. (2008, April 15). B-Mobile upgrades to multimedia services. Kuensel. p. 3.

Pek, S. S. (2003). Bhutan's media impact study. MediaCom Consultants, for Bhutan's Ministry of Information and Communications, Royal Government of Bhutan, online. Retrieved in September 2009, from www.unapcict.org/ecohub/resources/ bhutan

Pelden, S. (2008, February 25). Centennial-the latest FM. Kuensel. p. 11.

Penjore, D. (2005). Folktales and education: Role of Bhutanese folktales in value transmission. Centre for Bhutan Studies. Retrieved on 30 March 2009, from www.bhutanstudies.org.bt/admin/pubFiles/12-3.pdf

Penjore, U. (2006, February 1). Two private newspapers to start in April. Kuensel.

Quinn, S. (2006). Conversations on convergence. New York: Peter Lang Publishing.

Rapten, P. (2003). Mass media: Its consumption and impact on residents of Thimphu and rural areas on the internet. Centre for Bhutan Studies. Retrieved on 30 March 2009, from www.bhutanstudies.org.bt/admin/pubFiles/6.media.pdf

Roy, S. (2005). Globalisation, ICT and developing nations: Challenges in the information age. New Delhi: Sage Publications.

Thomas, P. (2007). Bhoomi, Gyan Ganga, e-governance and the right to information: ICTs and development in India. Telematics and Informatics, 26(1), 20-31. doi:10.1016/j.tele.2007.12.004

Thorburn, D. Henry. J. \& Brad. S. (2004). Rethinking media change: The aesthetics of transitions. Cambridge, Mass.: MIT Press.

Wangdi, K. (2005, September 26). Dzongkha: Out of window? Kuensel, n.p.

Wangchuk, S. (2007, September 10). Dzongkha font goes global. Kuensel, n.p.

Wilson, E. J. (2004). The information revolution and the developing countries. Cambridge, Mass.: MIT Press.

World Bank (2009) Bhutan, country assistance guide. Retrieved in September 2009, from http://go.worldbank.org/HVLTPS0I10

Zhao,W. Massey. B.L. Murphy, J. \& Fang, L. (2003). Cultural dimensions of website design and content. Prometheus, 21(1), 74-84. Retrieved on 30 March, from http:// web.biz.uwa.edu.au/staff/jmurphy/Cultural_Dimensions.pdf

Kinley Wangmo is a candidate in the Master of Journalism programme at the University of Queensland.

Dr John Cokley is a research and teaching academic in the School of Journalism and Communication, University of Queensland, Australia. j.cokley@uq.edu.au 